\begin{tabular}{|c|c|c|}
\hline Beitr. Ent. & Keltern & ISSN 0005-805X \\
\hline $\mathbf{5 6}(2006) 2$ & S. $479-480$ & 15.12 .2006 \\
\hline
\end{tabular}

\title{
Lebensweise und Verhalten von Insekten. Spektakuläre Videoaufnahmen nach Wahl
}

\author{
Mit 3 Figuren
}

\section{URS WYSS}

\section{Zusammenfassung}

Szenen aus dem Leben verschiedener Insekten werden seit einigen Jahren unter dem Stereomikroskop inszeniert und mit Hilfe hochauflösender schneller Videotechnik festgehalten. So sind z. B. die Entwicklung der Getreideblattlaus Sitobion avenae oder der Florfliege Chrysoperla carnea von der Geburt bzw. von der Eiablage bis zum erwachsenen Tier zu sehen. Darunter auch zum Teil spektakuläre und bisher nie zuvor in bewegten Bildern dokumentierte Sequenzen, wie z. B. der Angriff der Schlupfwespe Aphelinus abdominalis auf ihre Wirtsblattlaus oder der Mechanismus der Honigtauabgabe von Phloemsaugern.

\section{Schlüsselwörter}

Videofilm, Biologie. Verhalten, Insecta

\section{Summary}

For several years, scenes from the life of various insects have been put on stage under the stereomicroscope and captured with fast, high resolution video technology. As a result, for example, the development of the cereal aphid Sitobion avenae or the lacewing Chrysoperla carnea can be viewed from the birth respectively from the egg to the adult organism. Several sequences are spectacular and have never previously been documented in motion pictures, as for example the attack by the chalcidoid wasp Aphelinus abdominalis on its aphid host or the mechanism of honeydew excretion by phloem suckers.

\section{Key words}

Videofilm, Biology, Behaviour, Insecta

\section{Gezeigte Videofilme}

Die Getreideblattlaus Sitobion avenae. Entwicklung auf dem Sommerwirt - 8 min

Lebensweise und Entwicklung des Blattlausparasitoiden Aphelinus abdominalis. - $12 \mathrm{~min}$

Lebenszyklus der Florfliege Chrysoperla carnea. - 12 min

Blattläuse leben gefährlich. $-24 \mathrm{~min}$

Lebensweise und Entwicklung der Schwebfliege Episyrphus balteatus. - 13 min

Lebensweise und Entwicklung des Marienkäfers Adalia bipunctata. - 9 min 
Lebenszyklus der Haferblattlaus Rhopalosiphum padi. - 10 min

Lebensweise und Entwicklung der Spinnmilbe Tetranychus urticae. - 10 min

Schmierläuse und ihre natürlichen Feinde. -13 min

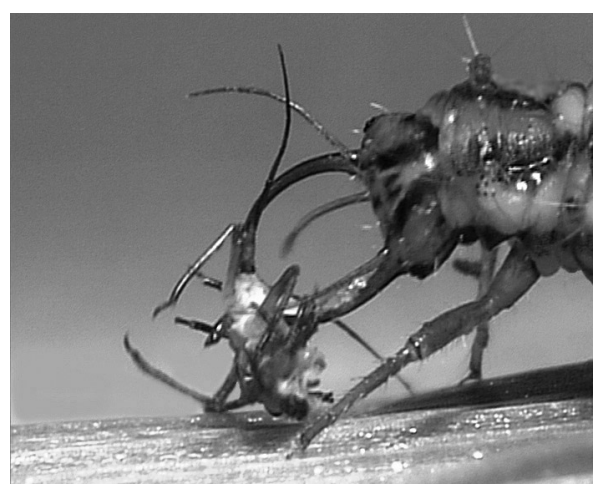

Fig. 1: Florfliegenlarve saugt Blattlaus aus.

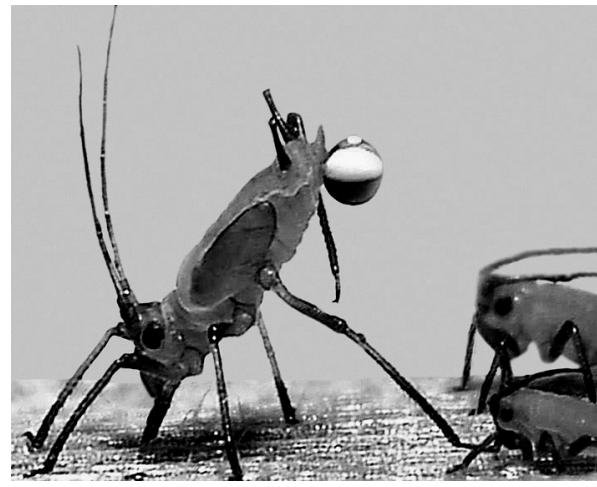

Fig. 3: Blattlaus Honigtauabgabe.

\section{Anschrift des Verfassers:}

Prof. Dr. URS Wyss

Institut für Phytopathologie, Universität Kiel

Hermann-Rodewald-Str. 9

D - 24118 Kiel

e-mail: uwyss@phytomed.uni-kiel.de

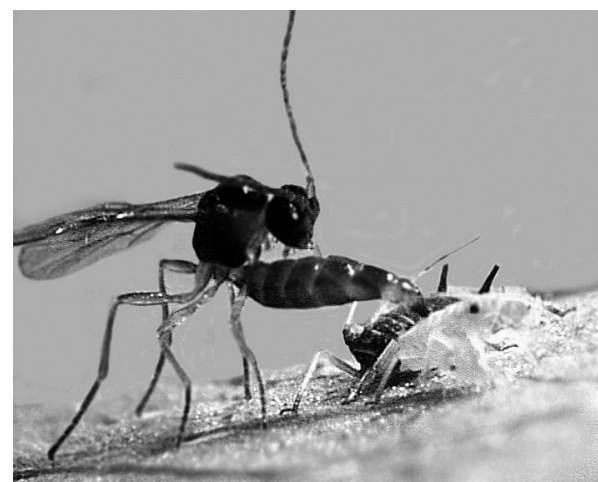

Fig. 2: Aphidius colemani Eiablage. 